medRxiv preprint doi: https://doi.org/10.1101/2020.07.12.20152298; this version posted July 14 , 2020. The copyright holder for this preprint

(which was not certified by peer review) is the author/funder, who has granted medRxiv a license to display the preprint in perpetuity.

It is made available under a CC-BY-NC 4.0 International license.

\title{
The effect of international travel restrictions on internal spread of COVID-19
}

Timothy W Russell ${ }^{1}$, Joseph T Wu ${ }^{2}$, Sam Clifford ${ }^{1}$, CMMID COVID-19 working group, W John Edmunds ${ }^{1}$, Adam J. Kucharski ${ }^{1}$, Mark Jit ${ }^{1,2}$

${ }^{1}$ Centre for Mathematical Modelling of Infectious Diseases, London School of Hygiene \& Tropical Medicine

${ }^{2}$ School of Public Health, The University of Hong Kong

The following authors were part of the Centre for Mathematical Modelling of Infectious Disease (CMMID) COVID-19 Working Group. Each contributed in processing, cleaning and interpretation of data, interpreted findings, contributed to the manuscript, and approved the work for publication: Matthew Quaife, Gwenan M Knight, Kathleen O'Reilly, Oliver Brady, Fiona Yueqian Sun, Joel Hellewell, Arminder K Deol, Megan Auzenbergs, James W Rudge, Christopher I Jarvis, Georgia R Gore-Langton, Thibaut Jombart, Charlie Diamond, James D Munday, Rachel Lowe, Sebastian Funk, Akira Endo, Damien C Tully, Jon C Emery, Petra Klepac, Stefan Flasche, Samuel Clifford, Stephane Hue, Katherine E. Atkins, Nicholas G. Davies, Anna M Foss, Quentin J Leclerc, Graham Medley, Amy Gimma, Rosalind M Eggo, Rein M G J Houben, Emily S Nightingale, Carl A B Pearson, Simon R Procter, Sam Abbott, Yang Liu, Nikos I Bosse, Hamish P Gibbs, David Simons, Billy J Quilty, Alicia Rosello, Sophie R Meakin, Kiesha Prem, Timothy W Russell, Kevin van Zandvoort, C Julian Villabona-Arenas.

Corresponding author: Mark Jit, Faculty of Epidemiology and Population Health, London School of Hygiene \& Tropical Medicine, Keppel Street, London WC1E 7HT, United Kingdom. Telephone: +44 (0)207927 2852. Email: mark.jit@Ishtm.ac.uk. 
medRxiv preprint doi: https://doi.org/10.1101/2020.07.12.20152298; this version posted July 14 , 2020. The copyright holder for this preprint (which was not certified by peer review) is the author/funder, who has granted medRxiv a license to display the preprint in perpetuity.

\section{Abstract}

Background: Countries have restricted international arrivals to delay the spread of COVID-19. These measures carry a high economic and social cost. They may have little impact on COVID-19 epidemics if there are many more cases resulting from local transmission compared to imported cases.

Methods: To inform decisions about international travel restrictions, we compared the ratio of expected COVID-19 cases from international travel (assuming no travel restrictions) to the expected COVID-19 cases arising from internal spread on an average day in May 2020 in each country. COVID-19 prevalence and incidence were estimated using a modelling framework that adjusts reported cases for under-ascertainment and asymptomatic infections.

Findings: With May 2019 travel volumes, imported cases account for $<10 \%$ of total incidence in 103 (95\% credible interval: 76 - 130) out of 142 countries, and <1\% in 48 (95\% Crl: 9 - 95). If we assume that travel would decrease compared to May 2019 even in the absence of formal restrictions, then imported cases account for $<10 \%$ of total incidence in $109-123$ countries and $<1 \%$ in $61-88$ countries (depending on the assumptions about travel reductions).

Interpretation: While countries can expect infected travellers to arrive in the absence of travel restrictions, in most countries these imported cases likely contribute little to local COVID-19 epidemics. Stringent travel restrictions may have limited impact on epidemic dynamics except in countries with low COVID-19 incidence and large numbers of arrivals from other countries.

Funding: Wellcome Trust, UK Department for International Development, European Commission, National Institute for Health Research, Medical Research Council, Bill \& Melinda Gates Foundation 
medRxiv preprint doi: https://doi.org/10.1101/2020.07.12.20152298; this version posted July 14 , 2020. The copyright holder for this preprint

\section{Research in context}

\section{Evidence before this study}

Countries are at different stages of COVID-19 epidemics, so many have implemented policies to minimise the risk of importing cases via international travel. Such policies include border closures, flight suspensions, quarantine and self-isolation on international arrivals. Searching PubMed and MedRxiv using the search: ("covid" OR "coronavirus" OR "SARS-CoV-2") AND ("travel" OR "restrictions" OR "flight" OR "flights" OR "border") from 1 January - 10 July 2020 returned 118 and 84 studies respectively, of which 39 were relevant to our study. These studies either concentrated in detail on the risk of importation to specific countries or used a single epidemiological or travel dataset to estimate risk. Most of them focused on the risk of COVID-19 introduction from China or other countries with cases earlier in 2020. No study combined country-specific travel data, prevalence estimates and incidence estimates to assess the global risk of importation relative to current local transmission within countries.

\section{Added value of this study}

We combined data on airline passengers and flight frequencies with estimates of COVID-19 prevalence and incidence (adjusted for underreporting and asymptomatic cases), to estimate the risk of imported cases, relative to the level of local transmission in each country. This allows decision makers to determine where travel restriction policies make large contributions to slowing local transmission, and where they have very little overall effect.

\section{Implications of all the available evidence}

In most countries, imported cases would make a relatively small contribution to local transmission, so travel restrictions would have very little effect on epidemics. Countries where travel restrictions would have a large effect on local transmission are those with 
medRxiv preprint doi: https://doi.org/10.1101/2020.07.12.20152298; this version posted July 14,2020 . The copyright holder for this preprint (which was not certified by peer review) is the author/funder, who has granted medRxiv a license to display the preprint in perpetuity. It is made available under a CC-BY-NC 4.0 International license.

strong travel links to countries with high COVID-19 prevalence and/or countries which have successfully managed to control their local outbreaks. 
medRxiv preprint doi: https://doi.org/10.1101/2020.07.12.20152298; this version posted July 14, 2020. The copyright holder for this preprint (which was not certified by peer review) is the author/funder, who has granted medRxiv a license to display the preprint in perpetuity.

\section{Introduction}

Coronavirus disease 2019 (COVID-19) is an illness caused by Severe Acute Respiratory Syndrome coronavirus 2 (SARS-CoV-2), which was first detected in Wuhan, China, in late 2019. Since then, it has been spread by travellers to almost every country in the world, and was declared a pandemic by the World Health Organization on 11 March $2020^{1}$. In the absence of effective pharmaceutical measures for prevention and treatment, countries have imposed a range of response measures to delay the spread of SARS-Cov-2, and hence enable health systems to cope with the expected sharp rise in health care demand.

One such intervention that has been widely used is international travel restrictions. Early travel restrictions focused on countries with early outbreaks (like China, Iran and Italy) but as SARS-CoV-2 spread to more countries, the list of origin countries on countries' travel restriction lists has grown. The World Tourism Organization reports that every country in the world had imposed some form of COVID-19-related travel restriction by 20 April 2020, the most extensive travel restrictions in history ${ }^{2}$. However, which restrictions were implemented differs from country to country and include border closures, flight suspensions, quarantine and self-isolation. Measures may also be applied indiscriminately or targeted at specific places of origin.

International travel restrictions carry a high economic and social cost. Much of global tourism, trade, business, education and labour mobility relies on cross-border movement of people. The United Nations Conference on Trade and Development (UNCTAD) estimates that the world's tourism sector will lose value worth $1.6-2.8 \%$ of global gross domestic product as a result of COVID-19; this excludes the value of lost non-tourism travel ${ }^{3}$. The social cost comes in the form of lost opportunities for family and friend reunion, international education and career development. According to International Health Regulations (2005) travel restrictions "shall not be more restrictive of international traffic and not more invasive or intrusive to persons than reasonably available alternatives that would achieve the appropriate level of health protection." ${ }^{4}$. Hence there are strong economic, humanitarian and legal reasons to only impose international travel restrictions when the benefits outweigh the costs. 
medRxiv preprint doi: https://doi.org/10.1101/2020.07.12.20152298; this version posted July 14, 2020. The copyright holder for this preprint (which was not certified by peer review) is the author/funder, who has granted medRxiv a license to display the preprint in perpetuity. It is made available under a CC-BY-NC 4.0 International license.

Travel restrictions have clear benefits when there are zero or few cases in the destination country. For instance, restrictions on travellers from Wuhan, or China more generally, in early 2020 may have contributed to slowing global spread of SARS-CoV-2 ${ }^{56}$. However, once case numbers within a country are sufficiently large that local outbreaks have been established and are self-sustaining, travel restrictions become less effective. For instance, the ban on European travellers to the United States on 12 March 2020 was too late to prevent a large epidemic in New York that already had been seeded mainly by European travellers ${ }^{7}$. Countries with established epidemics attempting to reduce COVID-19 incidence through stringent physical distancing measures such as lockdowns may impose travel restrictions to accelerate the reduction of new cases. However, this would only be effective if the number of cases being imported from international travellers would contribute substantially to overall incidence. Hence decisions around travel restrictions are complex; they need to take into account local transmission, COVID-19 prevalence in source countries of travellers and the volume of travel from those countries.

In this paper, we provide information to countries about the potential benefit of international travel restrictions by comparing the number of cases resulting from international travel to those resulting from local transmission in 142 countries.

\section{Methods}

\section{Prevalence by country}

Our analysis combines estimates of SARS-CoV-2 prevalence and incidence for each country with detailed flight data. The prevalence and incidence estimates are derived using statistical modelling methods described elsewhere ${ }^{8}$ and summarised here. First, the level of case ascertainment in each country is estimated using the ratio of a delay-adjusted country specific CFR and an assumed published "baseline" CFR ${ }^{9}$. Then, temporal variation in under-ascertainment is inferred using a Gaussian Process framework. Finally, these temporal under-ascertainment estimates are used to adjust the confirmed case time series 
medRxiv preprint doi: https://doi.org/10.1101/2020.07.12.20152298; this version posted July 14, 2020. The copyright holder for this preprint (which was not certified by peer review) is the author/funder, who has granted medRxiv a license to display the preprint in perpetuity. It is made available under a CC-BY-NC 4.0 International license.

10. The adjusted case data represent the estimated true number of symptomatic individuals in each country, which are typically significantly larger than the confirmed case numbers ${ }^{8,11}$.

Incidence is estimated as the number of new cases on the most recent day that the country in question had new cases, after adjusting for under-ascertainment and asymptomatic infections. Prevalence on each day is estimated as the sum of the new cases over the nine most recent days, i.e. assuming an infectious period of ten days ${ }^{12-14}$. This is then converted to a proportion by dividing by the country's population.

\section{International travellers}

International travel has reduced greatly since the COVID-19 pandemic began ${ }^{2}$ because of travel restrictions, but also because individual self-exclusion due to fear of infection and reduced business and tourism opportunities. Hence we considered four scenarios for international travel in May 2020 in the hypothetical case that there were no travel restrictions:

Scenario A: The number of travellers between each country was estimated using the number of passengers booked on flights, using data from the Official Aviation Guide (OAG) in May 2019, i.e. assuming that travel patterns in 2020 would be identical to 2019 in the absence of travel restrictions.

Scenario B: The OpenSky dataset provides data on the number of flights each day between pairs of countries. We adjusted the number of international travellers between countries downwards using the ratio of the number of flights in the OpenSky database in May 2019 and May 2020. This gave a mean reduction of 69\% (range 0\% - 99\%) across countries (Figure 3). Where data were not available, we applied the mean reduction across pairs of countries with data.

Scenarios C and D: The number of flights do not completely capture the reduction in passengers, since aircraft occupancy has also decreased in 2020. The International Air Transport Association (IATA) projects that passenger departures will decline by $50.6 \%$ in 
medRxiv preprint doi: https://doi.org/10.1101/2020.07.12.20152298; this version posted July 14 , 2020. The copyright holder for this preprint

(which was not certified by peer review) is the author/funder, who has granted medRxiv a license to display the preprint in perpetuity.

t is made available under a CC-BY-NC 4.0 International license.

2020 compared to $2019^{15}$. In the absence of travel restrictions, we assumed two scenarios about international travellers: $25 \%$ reduction (scenario $\mathrm{C}$ ) and $50 \%$ reduction (scenario $\mathrm{D}$ ).

\section{Imported cases}

The number of cases imported from a source country to a destination country on a particular date is estimated as the product of the prevalence on that date in the source country multiplied by the number of travellers from that country to the destination country on a single day in May 2020. The total number of imported cases on that date is then estimated by summing the cases imported from all countries with travellers to the destination country. We then calculated the ratio of imported cases to total incidence.

For countries where imported cases are predicted to account for over $1 \%$ of local incidence, we estimated the proportion of incoming travellers that needed to be averted in order to bring this proportion below $1 \%$. We assumed that incoming travellers would be averted in order of COVID-19 prevalence in their countries of origin, i.e. averting travellers from the highest prevalence country first.

\section{Results}

Figure 1 shows the risk rating for each country, based on the ratio of imported cases to total incidence, for different scenarios about passenger reductions in May 2020. Even in the worst-case scenario of no change in travel patterns compared to May 2019 in the absence of travel restrictions (Figure 1, Panel A), we estimate that in 109 countries out of 142 modelled imported cases contribute to $<10 \%$ of local incidence.

There is little change in country risk ratings when we assume that international travellers in 2020 decreased compared to 2019. In particular, most countries where imported cases are estimated to contribute to $10 \%$ or more of local incidence (including China, Thailand and Australia) remain in that category across all scenarios. The scenarios assuming reduction in travel have the largest effect on European and Latin American countries, where imported 
medRxiv preprint doi: https://doi.org/10.1101/2020.07.12.20152298; this version posted July 14, 2020. The copyright holder for this preprint (which was not certified by peer review) is the author/funder, who has granted medRxiv a license to display the preprint in perpetuity.

cases are estimated to fall below $1 \%$ of local incidence as assumed travellers to those regions decrease.

Figure 2 shows the proportion by which international arrivals need to be averted to bring imported cases to below $1 \%$ of local incidence, in all countries in scenario B where it is over 1\%. Most of these countries would need to avert the majority of their international arrivals, although there are a few that may be able to bring imported cases to below $1 \%$ of local incidence by averting less than a quarter of arrivals. Figure 3 shows the relationship between imported cases and local outbreak size.

\section{Discussion}

Almost all countries have reported COVID-19 cases, but they differ in the stage of the pandemic they are in (as of July 2020). Many countries in East Asia, Australasia and Europe are well past peak incidence, with some having reduced incidence to very low levels ${ }^{10}$. Conversely in other countries, incidence remains high and may be increasing. Hence recommendations about international travel restrictions cannot be applied uniformly, but instead need to take into account country circumstances in terms of within-country transmission and connectedness to countries with high prevalence.

Using estimated COVID-19 prevalence in 142 countries together with international travel data between countries, we categorise countries according to the extent to which imported cases may contribute to local transmission in the absence of travel restrictions. In our worst-case scenario (from the perspective of case importation), we assume that travel patterns in May 2019 would hold in May 2020 in the absence of travel restrictions. Even in this scenario, we find that in most countries, imported cases would account for less than $10 \%$ of local incidence in the absence of travel restrictions. In other scenarios, we assume that international travel would have decreased in May 2020 (compared to May 2019) even without travel restrictions. In one of these scenarios, we find that in most countries, imported cases would account for less than $10 \%$ of local incidence in the absence of travel restrictions. 

medRxiv preprint doi: https://doi.org/10.1101/2020.07.12.20152298; this version posted July 14,2020 . The copyright holder for this preprint
(which was not certified by peer review) is the author/funder, who has granted medRxiv a license to display the preprint in perpetuity. It is made available under a CC-BY-NC 4.0 International license.

Hence, our results suggest that in May 2020, travel restrictions may have done little in most countries to change the course of local epidemics, and may not be justified given the high economic and social costs required to prevent the arrival of travellers representing less than $10 \%$ (or in many cases, less than 1\%) of new cases. In most of the countries where this proportion is greater than $1 \%$, it can be brought below $1 \%$ by selective restrictions imposed only on travellers from the highest prevalence countries. However, there are a few countries that would have to prevent entry by almost all international travellers to reach this threshold. These are generally countries where control of local epidemics have been achieved. For instance, both New Zealand and China have low enough incidence that the expected number of imported cases ( 4 and 69 , respectively) is greater than local incidence ( 2 and 39), so imported cases pose a real risk of triggering a second local epidemic wave (Table S1).

Some countries with moderately large local epidemics in May 2020 (such as some countries in the Americas) still have a moderate level of risk associated with imported cases under the worst-case traveller volume scenario (scenario A), because of their strong connectedness to other high prevalence countries. Imported cases in these countries may be insufficient to drive local epidemics on its own, but may become important in driving epidemics that have already started if countries succeed in reducing local reproduction numbers close to 1 , the level at which each new generation of infected cases is smaller than the last.

Our estimates involve simplifying assumptions. We assume that international arrivals in a country have the same probability of being infected as any other person selected at random from the source country. In practice, the risk of infected arrivals is likely to be lower because symptomatic cases are less likely to travel as they may be recuperating at home or in hospital. For those who do attempt to travel, they may be detected during exit screening in the source country or entry screening in the destination country. For those in their incubation period at the time of travel, they may develop symptoms and be detected or sef-declare illness upon arrival. We also did not consider the effect of outbound travellers on local transmission. Travel restrictions would also prevent infected travellers from leaving their source country, which would reduce the number of cases locally, and hence partially mitigate the impact of infected inbound travellers. All these limitations result in 
medRxiv preprint doi: https://doi.org/10.1101/2020.07.12.20152298; this version posted July 14 , 2020. The copyright holder for this preprint

(which was not certified by peer review) is the author/funder, who has granted medRxiv a license to display the preprint in perpetuity.

It is made available under a CC-BY-NC 4.0 International license.

overestimating the number of COVID-19 importations that would occur without travel restrictions. However, one limitation in the opposite direction is that we assume that all international travel occurs through flights, so our analysis may not accurately capture the risk of importation between countries that normally have a high volume of land traffic (such as rail and road travel between countries in continental Europe).

Our prevalence and incidence estimates are approximate and may overestimate incidence in countries with younger overall population structures and underestimate it in countries with older populations. ${ }^{8}$ of these estimates. Furthermore, countries with very low case numbers are excluded from our analysis, as it is not possible to accurately estimate incidence and prevalence estimates for such countries.

Despite these limitations, the categorisation of countries is broadly stable over sensitivity analyses around both country prevalence and incidence estimates, and international travel patterns. They indicate that strict untargeted travel restrictions are probably unjustified in most countries, other than those that have both good international travel connections and very low local COVID-19 incidence. Countries needing to make detailed decisions about travel restrictions or quarantine white lists can use the methods presented here combined with the most current and accurate local data available. 
medRxiv preprint doi: https://doi.org/10.1101/2020.07.12.20152298; this version posted July 14 , 2020. The copyright holder for this preprint

(which was not certified by peer review) is the author/funder, who has granted medRxiv a license to display the preprint in perpetuity.

It is made available under a CC-BY-NC 4.0 International license.

\section{Contributions}

MJ and TWR conceived the study. TWR, JTW and MJ compiled and analysed data. TWR, AJK and WJE estimated country COVID-19 prevalence and incidence. TWR, SC and MJ designed the model and conducted the analyses. All authors contributed to manuscript writing and approved the final version.

\section{Code and data availability}

The data used in this analysis is publicly available case and death time series data, available from the European Centre for Disease Control ${ }^{10}$. The code used for the analysis in this paper is available online (https://github.com/thimotei/covid travel restrictions), as is the code used to produce under-reporting estimates, which form the basis for the country-specific prevalence and incidence estimates (https://github.com/thimotei/covid underreporting).

\section{Declaration of interests}

We declare no competing interests.

\section{Acknowledgments}

The following funding sources are acknowledged as providing funding for the named authors. MJ was partly funded by the Bill \& Melinda Gates Foundation (INV-003174); MJ was partly funded by the National Institute for Health Research (NIHR) using UK aid from the UK Government to support global health research. The views expressed in this publication are those of the author(s) and not necessarily those of the NIHR or the UK Department of Health and Social Care). MJ has received funding from the European Union's Horizon 2020 research and innovation programme - project EpiPose (101003688: WJE, SC). This project was funded by the Wellcome Trust (206250/Z/17/Z: AJK, 208812/Z/17/Z: SC).

The following funding sources are acknowledged as providing funding for the working group authors. Alan Turing Institute (AE). BBSRC LIDP (BB/M009513/1: DS). This research was 

medRxiv preprint doi: https://doi.org/10.1101/2020.07.12.20152298; this version posted July 14,2020 . The copyright holder for this preprint
(which was not certified by peer review) is the author/funder, who has granted medRxiv a license to display the preprint in perpetuity. It is made available under a CC-BY-NC 4.0 International license

partly funded by the Bill \& Melinda Gates Foundation (INV-001754: MQ; INV-003174: KP, YL; NTD Modelling Consortium OPP1184344: CABP, GM; OPP1180644: SRP; OPP1183986: ESN; OPP1191821: KO'R, MA). DFID/Wellcome Trust (Epidemic Preparedness Coronavirus research programme 221303/Z/20/Z: CABP, KvZ). DTRA (HDTRA1-18-1-0051: JWR). Elrha R2HC/UK DFID/Wellcome Trust/This research was partly funded by the National Institute for Health Research (NIHR) using UK aid from the UK Government to support global health research. The views expressed in this publication are those of the author(s) and not necessarily those of the NIHR or the UK Department of Health and Social Care (KvZ). ERC Starting Grant (\#757688: CJVA, KEA; \#757699: JCE, RMGJH; 757699: MQ). This project has received funding from the European Union's Horizon 2020 research and innovation programme - project EpiPose (101003688: KP, PK, YL). This research was partly funded by the Global Challenges Research Fund (GCRF) project 'RECAP' managed through RCUK and ESRC (ES/P010873/1: AG, CIJ, TJ). HDR UK (MR/S003975/1: RME). Nakajima Foundation (AE). NIHR (16/137/109: CD, FYS, YL; 16/137/109 \& 16/136/46: BJQ; Health Protection Research Unit for Immunisation NIHR200929: NGD; Health Protection Research Unit for Modelling Methodology HPRU-2012-10096: TJ; PR-OD-1017-20002: AR). Royal Society (Dorothy Hodgkin Fellowship: RL; RP\EA\180004: PK). UK DHSC/UK Aid/NIHR (ITCRZ 03010: HPG). UK MRC (LID DTP MR/N013638/1: GRGL, QJL; MC_PC 19065: RME; MR/P014658/1: GMK). Authors of this research receive funding from UK Public Health Rapid Support Team funded by the United Kingdom Department of Health and Social Care (TJ). Wellcome Trust (206250/Z/17/Z: TWR; 206471/Z/17/Z: OJB; 208812/Z/17/Z: SFlasche; 210758/Z/18/Z: JDM, $J H, N I B, S A$, SFunk, SRM). No funding (AKD, AMF, DCT, SH). 
medRxiv preprint doi: https://doi.org/10.1101/2020.07.12.20152298; this version posted July 14,2020 . The copyright holder for this preprint

(which was not certified by peer review) is the author/funder, who has granted medRxiv a license to display the preprint in perpetuity.

\section{List of tables}

Table 1. Summary of the model parameters. We sum the time to infectiousness and infectious period to arrive at prevalence estimates.

\begin{tabular}{|c|c|c|c|}
\hline Model parameter & Description & Value & Source \\
\hline $\begin{array}{l}\text { Incubation period } \\
\text { (days) }\end{array}$ & $\begin{array}{l}\text { Time from exposure } \\
\text { to onset of } \\
\text { symptoms. }\end{array}$ & $\begin{array}{c}\Gamma\left(\mu=5.5, \sigma^{2}=6.5\right) \\
\text { Median: } 5.1 \text { days } \\
\text { 97.5\%: } 11.5 \text { days }\end{array}$ & Lauer et al. ${ }^{13}$ \\
\hline $\begin{array}{c}\text { Time to } \\
\text { infectiousness } \\
\text { (symptomatic cases) }\end{array}$ & $\begin{array}{l}\text { Time after exposure } \\
\text { (and before onset) } \\
\text { from which } \\
\text { pre-symptomatic } \\
\text { transmission can } \\
\text { occur. }\end{array}$ & $\begin{array}{l}\text { Median: } 3.4 \text { days } \\
\text { IQR: }(2.3,4.9) \text { days } \\
\text { 95\%: }(0.9,8.6) \text { days }\end{array}$ & $\begin{array}{c}\text { Derived from } \\
\text { He et al. }{ }^{12}\end{array}$ \\
\hline $\begin{array}{c}\text { Infectious period } \\
\text { (symptomatic cases, } \\
\text { days) }\end{array}$ & $\begin{array}{c}\text { Time after } \\
\text { incubation period } \\
\text { during which case is } \\
\text { able to infect others }\end{array}$ & $\begin{array}{l}\text { Median: } 7.1 \text { days } \\
\text { IQR: }(5.7,8.5) \text { days } \\
\text { 95\%: }(2.5,11.6) \text { days }\end{array}$ & $\begin{array}{l}\text { Derived from } \\
\text { Wölfel et al. }{ }^{14}\end{array}$ \\
\hline
\end{tabular}


medRxiv preprint doi: https://doi.org/10.1101/2020.07.12.20152298; this version posted July 14,2020 . The copyright holder for this preprint

(which was not certified by peer review) is the author/funder, who has granted medRxiv a license to display the preprint in perpetuity.

\section{List of Figure captions}

Figure 1. Risk rating by country, in the absence of international travel restrictions, in each of the four scenarios about international travellers in May 2020. (A) Travel assumed to be at the same levels as May 2019. (B) Traveller numbers scaled downwards based on the reduction in flights in May 2020 reported by OpenSky. (C) Traveller numbers scaled down by 25\%. (D) Traveller numbers scaled down by $50 \%$.

Figure 2. Percentage reduction in passenger numbers required for countries in scenario $B$ where imported cases account for more than $1 \%$ of local incidence to bring that proportion below $1 \%$. Countries are grouped by United Nations Region (Oc. is Oceania).

Figure 3. Scatter plot showing the percentage of local daily incidence that daily imported cases represent, where the expected number of imported cases is at least $1 \%$ of local incidence. The dashed line represents $10 \%$ of local incidence from imported cases. NB: For New Zealand (NZL) and China (CHN), imported cases represent at least $100 \%$ of local incidence. 
medRxiv preprint doi: https://doi.org/10.1101/2020.07.12.20152298; this version posted July 14,2020 . The copyright holder for this preprint (which was not certified by peer review) is the author/funder, who has granted medRxiv a license to display the preprint in perpetuity.

\section{References}

1 World Health Organization. WHO Director-General's opening remarks at the media briefing on COVID-19 - 11 March 2020. 2020; published online March 11.

https://www.who.int/dg/speeches/detail/who-director-general-s-opening-remarks-at-th e-media-briefing-on-covid-19---11-march-2020 (accessed July 5, 2020).

2 World Tourism Organization. COVID-19 Related Travel Restrictions. A Global Review for Tourism. Second report as of 28 April 2020. 2020; published online April 28.

https://webunwto.s3.eu-west-1.amazonaws.com/s3fs-public/2020-04/TravelRestrictions \%20-\%2028\%20April.pdf.

3 United Nations Conference on Trade and Development (UNCTAD). unctad.org | Covid-19 and Tourism: Assessing the Economic Consequences. 2020

https://unctad.org/en/PublicationsLibrary/ditcinf2020d3_en.pdf (accessed July 8, 2020).

4 Habibi R, Burci GL, de Campos TC, et al. Do not violate the International Health Regulations during the COVID-19 outbreak. Lancet Lond Eng/ 2020; 395: 664-6.

5 Chinazzi M, Davis JT, Ajelli M, et al. The effect of travel restrictions on the spread of the 2019 novel coronavirus (COVID-19) outbreak. Science 2020; published online March. DOI:10.1126/SCIENCE.ABA9757.

6 Wells CR, Sah P, Moghadas SM, et al. Impact of international travel and border control measures on the global spread of the novel 2019 coronavirus outbreak. Proc Natl Acad Sci U S A 2020; 117: 7504-9.

7 Gonzalez-Reiche AS, Hernandez MM, Sullivan MJ, et al. Introductions and early spread of SARS-CoV-2 in the New York City area. Science 2020; published online May 29. DOI:10.1126/science.abc1917.

8 Russell TW, Hellewell J, Abbott S, et al. Using a delay-adjusted case fatality ratio to estimate under-reporting. Using Delay-Adjust. Case Fatal. Ratio Estim. -Report. 2020; published online July 5 .

https://cmmid.github.io/topics/covid19/global_cfr_estimates.html.

9 Verity R, Okell LC, Dorigatti I, et al. Estimates of the severity of coronavirus disease 2019: a model-based analysis. Lancet Infect Dis 2020; 20: 669-77.

10 European Centre for Disease Prevention and Control. Download today's data on the geographic distribution of COVID-19 cases worldwide. 2020; published online July 11. https://www.ecdc.europa.eu/en/publications-data/download-todays-data-geographic-di stribution-covid-19-cases-worldwide (accessed July 12, 2020).

$11 \mathrm{Li} \mathrm{R}$, Pei S, Chen B, et al. Substantial undocumented infection facilitates the rapid dissemination of novel coronavirus (SARS-CoV-2). Science 2020; 368: 489-93. 
medRxiv preprint doi: https://doi.org/10.1101/2020.07.12.20152298; this version posted July 14,2020 . The copyright holder for this preprint

(which was not certified by peer review) is the author/funder, who has granted medRxiv a license to display the preprint in perpetuity.

is made available under a CC-BY-NC 4.0 International license.

12 He X, Lau EHY, Wu P, et al. Temporal dynamics in viral shedding and transmissibility of COVID-19. Nat Med 2020; 26: 672-5.

13 Lauer SA, Grantz KH, Bi Q, et al. The Incubation Period of Coronavirus Disease 2019 (COVID-19) From Publicly Reported Confirmed Cases: Estimation and Application. Ann Intern Med 2020; 172: 577-82.

14 Wölfel R, Corman VM, Guggemos W, et al. Virological assessment of hospitalized patients with COVID-2019. Nature 2020; 581: 465-9.

15 International Air Transport Association. Economic Performance of the Airline Industry. International Air Transport Association, 2020 https://www.iata.org/en/iata-repository/publications/economic-reports/airline-industryeconomic-performance-june-2020-report/ (accessed July 5, 2020). 

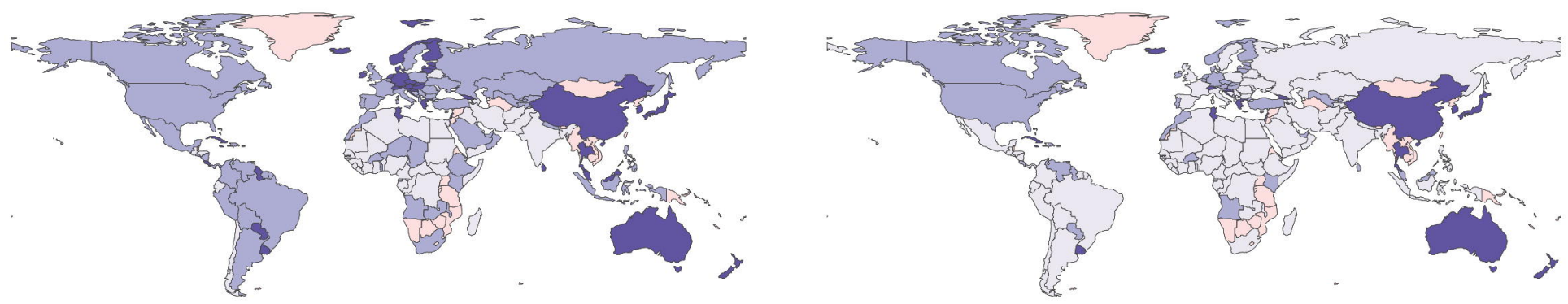

C: Traveller levels scaled down by $25 \%$

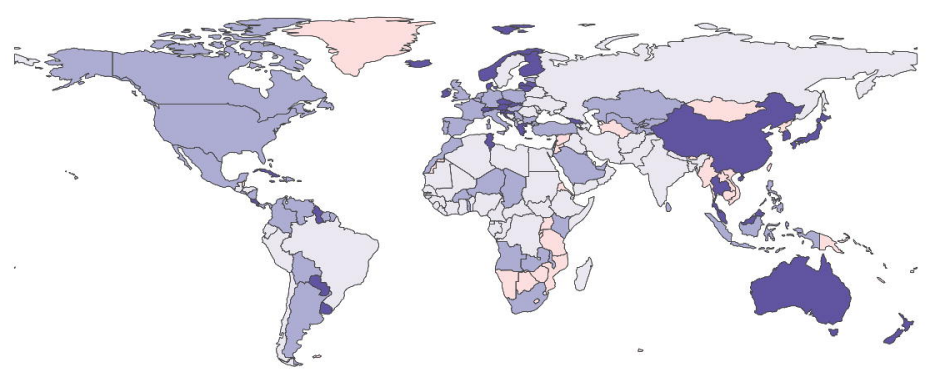

D. Traveller levels scaled down by $50 \%$

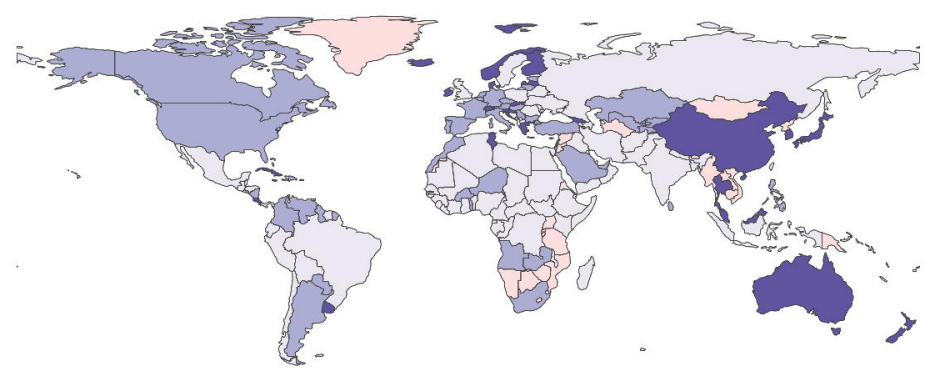

Expected imported cases as percentage of estimated local incidence $\square$ Less than $1 \% \square$ Between $1 \%$ and $10 \% \square$ Greater than $10 \% \square$ No data 


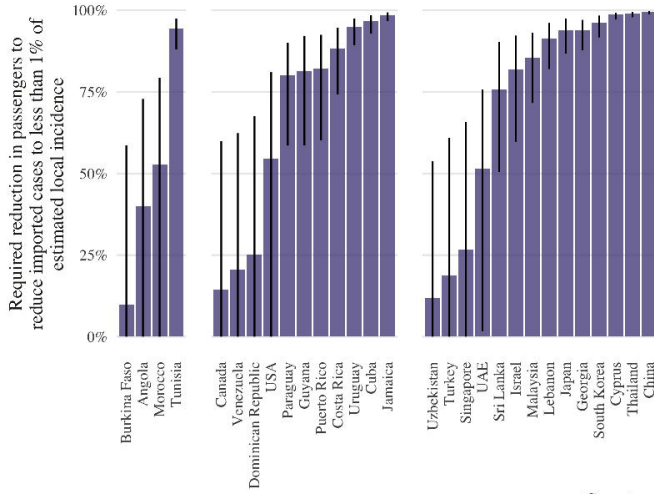


Traveller levels scaled down by reductions in OpenSky May 2020

Countries with imported cases at least $1 \%$ of estimated local incidence

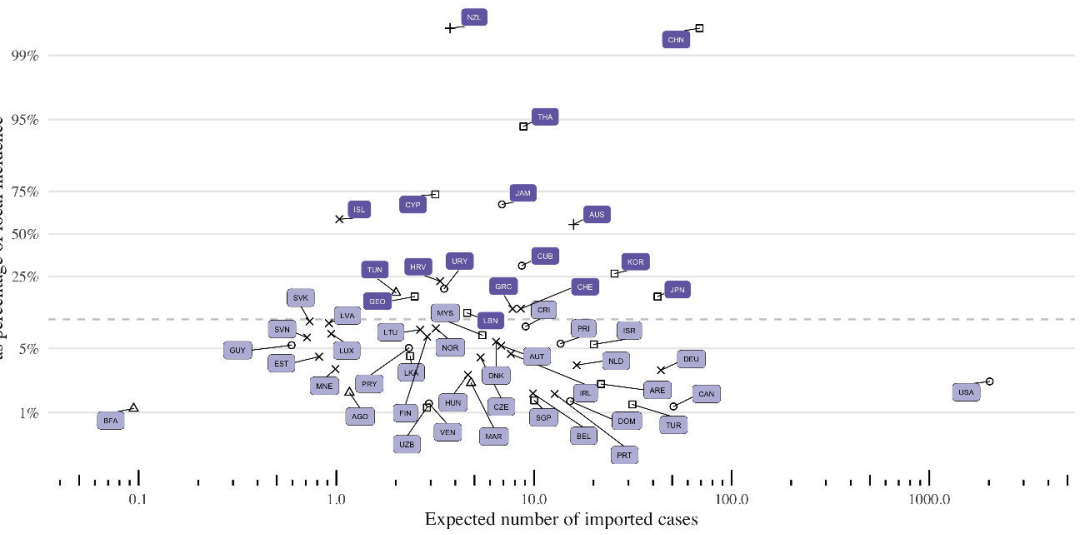

Expected number of imported cases as percentage of estimated local incidence 